\title{
Okul Yöneticilerinin İletişim Becerilerinin Geliştirilmesinde Modül Temelli Uygulamalar*
}

\section{Module Based Applications Developing Communication Skills of School Administrators}

\author{
Gönül ŞENER ${ }^{* *}$, Mukadder BOYDAK ÖZAN***
}

\begin{abstract}
Öz: Araştırmanın amacı, modül temelli uygulamalar ile okul yöneticilerinin iletişim becerilerinin gelişimini sağlamaktır. Araştırma, 2014-2015 eğitim öğretim y1lında Elazığ il merkezinde görev yapan ve yönetici rotasyonundan etkilenmemiş okul yöneticileri üzerinde yürütülmüştür. Araştırmada deney ve kontrol olmak üzere iki grup belirlenmiştir. Deney grubuna toplam 12 saat modül temelli yüz yüze eğitimler verilmiş, bunun yanı sıra moodle öğretim yönetim sistemleri üzerinden de uygulamalar devam ettirilmiştir. Deneysel desene ilişkin başarı testi yöneticilere öntest ve sontest olarak uygulanmıştır. Araştırma sonucunda, iletişim yönetimi becerileri uygulamalarına katılan deney grubundaki okul yöneticilerinin, uygulamalara katılmayan kontrol grubundaki okul yöneticilerine göre başarılarının arttığ kendi iletişim becerilerine ilişkin tutumlarının olumlu yönde değiştiği görülmüş̧ür. Bu sonuçlar doğrultusunda eğitim fakültelerinde iletişim becerileri ile ilgili programların veya derslerin konulması, yöneticiliğe başlayacakların iletişim becerileri ile ilgili eğitime alındıktan sonra göreve başlatılmaları, görevde olanların hizmet içi eğitimlerle iletişim becerilerinin geliştirilmesi, bu doğrultuda ilgili kursseminer ve eğitimlere alınmaları önerilmiştir.

Anahtar Kelimeler: İletişim becerileri, modül, okul yöneticisi
\end{abstract}

\begin{abstract}
The aim of the research is to ensure the development of communication skills of school administrators with module-based practices, in accordance with this relationship. The research was carried out on school administrators, who worked in the city center of Elazığ and were not affected by administrator rotation, in 2014-2015 academic year. Two groups, experimental and control groups, were determined in the research. A total of 12 hours module-based face to face trainings were provided for the experimental group and practices were also maintained over moodle teaching management systems. The achievement test for experimental design was applied to the administrators as pretest and posttest. As a result of the research; it was observed that the success of the school administrators in the experimental group who participated in communication management skills practices increased compared to the school administrators in the control group who did not participate in practices, and that their attitudes regarding their own ways of communication positively changed. In accordance with these results, the followings were proposed; programs or courses related to communication skills in faculties of education should be introduced, those who will begin work as administrators should start to work after participating the trainings related to communication skills, the communication skills of those working should be developed through in-service trainings, and they should participate in the relevant course-seminar and trainings in this respect.
\end{abstract}

Keywords: Communication skills, module, school administrators

\section{Giriş}

İletişim, insanların duygularını, düşüncelerini, hayallerini ve sorunlarını birbirlerine aktarmada, insan yaşantısının en önemli boyutunu oluşturur. İnsanlar hayata gözlerini açtığı ilk andan itibaren hem doğa ile etkileşimde bulunmak hem de çevresindeki uyaranları anlamlı kılmak için

\footnotetext{
* Bu makale "Okul Yöneticilerinin İletişim Becerilerinin Örgütsel Değişkenler Üzerindeki Etkisi ve Modül Temelli Uygulamalar" isimli doktora tez çalışmasından üretilmiştir.

** Dr. Öğr. Üyesi, Munzur Üniversitesi, Çemişgezek MYO, Tunceli-Türkiye, ORCİD: 0000-0003-3212-7703, eposta: gonulsener@munzur.edu.tr.

***Prof. Dr. Mukadder Boydak Özan, Fırat Üniversitesi, Eğitim Fakültesi, Elazı̆g-Türkiye, ORCİD: 0000-00015690-6985, e-posta: mboydak@ firat.edu.tr
} 
diğer insanlarla iletişime geçmek zorundadır. İletişim, ilk olarak anlamsız seslere yüklenilen anlamlar, duvarlara çizilen resimler, yazının icadıyla yazılı iletişim ve çağımızın ileri teknolojisine kadar bir gelişim dönemi içerisine girmiştir (Aydoğan ve Kaşkaya, 2010, s. 4; Güngör, 2011, s. 36). Böylece iletişim insanların yalnız kalma korkularını aşmalarından, birlikte durup birlikte üretebilmelerine, kültürler oluşturmalarına, hatta uygarlıklar kurmalarına kadar her durumda gerekli olan bir olgu haline gelmiştir (Orhon ve Eriş, 2012). İletişimin insanla başlayıp devam eden ve insan hayatı devam ettikçe de devam edecek bir süreç olduğunu söylemek mümkündür.

Yaşamın her alanında bu denli öneme sahip olan iletişim, aynı zamanda toplumsal yaşamın da temelini oluşturmaktadır. İletişimin önemi, insanların daha fazla bir arada olduğu meslek gruplarında, örgütlerin amaçlarına ulaşma derecesini belirlemede her geçen gün artmaktadır (Özdemirci, 2006, s.2). Özellikle 1970'li yıllardan sonra yönetim anlayışının katı, bürokratik ve mekanik yapıdan uzaklaşarak yeni boyutlar kazanmaya başlamasıyla (Saran, 2001), yalnızca verimliliği ve mevcut durumu korumayı temele alan, mesafeli, korkutucu, otoriter, çalışanlarıyla mümkün olduğunca az iletişim kuran klasik yönetici anlayışını değiştirmiş, yeni bir yönetici profili ortaya çıkarmıştır. Bu yeni yöneticilerden çalışanları motive edebilmesi, empatik olabilmesi, sinerji oluşturup örgütsel etkinliği sağlayabilmesi ve bütün bunları yaparken çalışanlarıyla etkili iletişim kurabilmesi beklenmektedir (Tengilimoğlu, 2005).

Bir örgütte herkesin aynı dilden konuşuyor olabilmesi için örgütün amaçları, örgütün vizyonu, misyonu, organizasyon yapısı, bu yapı içindeki sorumluluk ve yetki dağılımı gibi birtakım önemli konularla ilgili benzer şeyleri söyleyebiliyor olmaları gerekmektedir. Bunun başarılabilmesinde iletişim süreçleri etkili bir rol oynamaktadır (Eroğlu, 2011, s.37). Yapılan çalışmalar, çalışanların kurumlarına ilişkin olumsuz tutumlarını (örgütsel sinizm) açıklamada, yöneticilerin iletişim becerilerinin önemli değişkenlerden biri olduğunu göstermektedir (Uzun ve Ayı, 2016).

Bir örgütte iletişime yön veren, iletişim sürecini başlatan ve kurulacak iletişimin niteliğini belirleyen en önemli öğe, bilgiyi aktaran yöneticidir. Çünkü örgütün kendisine verdiği yetkiye dayalı olarak alt kademedeki personele göre daha etkin bir konuma sahiptir. Gerek bilgiyi aktaranın, gerekse alanın sahip olduğu bilgi, beceri, tutum ve amacı bilginin doğru bir biçimde algılanmasını etkileyebilmektedir. İletişimin başlıca amacı; politik kararları etkilemek, geri besleme sağlamak ve örgütteki gelişmeler hakkında personele sürekli bilgi vermektir (Celep, 1992). İletişim süreci, insan davranışlarını değiştirmek, kişiler ve gruplar arası ilişkileri geliştirmek, görevleri gerçekleştirmek, örgütte bir haberleşme ağı kurmak ve etkili bir eşgüdümü sağlamak amacıyla kullanılır (Taymaz, 2000, s.41). İletişimde başarılı okul müdürlerinin daha etkili olduğu bilinen bir olgudur (Bursalığlu, 2011, s. 41-42; Callan, 1993, s.22-23; Çelikkaya, 1998, s. 91). Etkili bir iletişimi gerçekleştirmeden etkili bir yönetim gerçekleştirmek ise olası değildir (Roebuck, 2000, s. 10).

Yöneticiler ve çalışanlar arasındaki iletişim, örgütteki performansın etkililiği açısından önemli bir etkendir. Çalışanlar arasında birlik ve beraberliği sağlamak yöneticinin görevidir. Bütün bunları gerçekleştirebilmek için okul yöneticisinin düşünce, fikir ve duygularını rahat ve etkili bir şekilde ifade edebilmesi, ikna edici, liderlik özelliklerini taşıyan, iyi bir dinleyici olması gerekmektedir. Eğitim yönetiminde emirlerin, bilgilerin, fikirlerin, düşüncelerin, sorunların çalışanlar arasında ve okul içerisinde sağlıklı bir şekilde iletilmesi, iletişimin doğru ve etkili işlemesine bağlıdır. Günümüzde yaşadığımız hızlı değişim ve gelişmeler, iletişim yeterliliğine sahip yöneticilere olan ihtiyacı artırmıştır (Demir, 2000). Birçok örgütün başarısızlığının nedenleri arasında iletişim sürecinin işleyişindeki bozukluklar yer almaktadır. $\mathrm{Bu}$ sürecin gerektiği gibi devam edememesi; zaman, para ve kaliteli insan gücü gibi maliyeti oldukça yüksek olan kayıplara neden olabilmektedir (Geçikli, 2004, s. 106-107). Bu nedenle örgütsel etkililiğin sağlanmasında okul yöneticilerinin iletişim becerileri konusunda uzman kişiler olmaları beklenmektedir. Bu uzmanlığın sağlanması alınan eğitimlerle mümkün olmaktadir.

Ayrıntılı olarak incelenen literatürde; iletişimin yönetsel boyutuyla ilgili teorik bilgilere ve betimsel çalışmalara fazlasıyla yer verildiği görülmekle birlikte, yöneticilere iletişim 
yönetimi becerileri kazandırmaya yönelik uygulamalı çalışmalara ulaşılamamıştır. Ayrıca yapılan çalışmalar okul yöneticilerinin iletişim becerilerinin yetersiz olduğunu göstermektedir (Arslantaş, 2002; Celep, 1992; Çelik, 2007; Çetinkaya, 2011; Dağl1, 2000; Demircan, 2001; Ersoy, 2006; Güneş, 2007; Gürses, 2006; Özbek, 1998). Okulda yöneticileri; öğretmenler, öğrenciler ve veliler arasında karşılıklı saygı ve güvene dayalı devam eden bir iletişim süreci sağlamalıdır. $\mathrm{Bu}$ süreç öğrencilerin gelişimini ve akademik başarısını etkileyebilmektedir. Birçok öğrenci, okuldaki iletişim ile ilgili sorunlardan dolayı okuldan ayrılmakta veya başarısız olmaktadır. Okullardaki iletişim sürecinin bütün boyutlarıyla sağlıklı bir şekilde devam ettirilmesinde yöneticilere önemli görevler düşmektedir.

$\mathrm{Bu}$ araştırma ile yöneticilerin okullarında etkililiğin sağlanması noktasında iletişimin önemini bilmelerini gerek öğretmenlerle gerekse öğrenci ve velilerle olan iletişiminde etkin iletişim becerilerini sergilemelerini, bu becerilerin kişisel ve mesleki gelişimlerine katk1 sağlamasını, aynı zamanda alandaki boşluğu doldurması hedeflenmektedir. Araştırmanın genel amac1; modül temelli uygulamalar ile okul yöneticilerinin iletişim becerilerinin gelişimini sağlamaktır. Bu amacın gerçekleşesine dönük aşağıdaki denenceler sınanmıştır.

Denence 1: İletişim yönetimi becerileri geliştirme uygulamalarına katılan deney grubundaki okul yöneticilerinin başarı testinin tümünden aldıkları öntest-sontest puanları arasında, sontest puanları lehine anlamlı bir fark vardır.

Denence 2: İletişim yönetimi becerileri geliştirme uygulamalarına katılmayan kontrol grubundaki okul yöneticilerinin başarı testinin tümünden aldıkları öntest-sontest puanları arasında, sontest puanları lehine anlamlı bir fark yoktur.

Denence 3: Deney ve kontrol grubundaki okul yöneticilerinin başarı testinden aldıkları sontest puanları arasında, deney grubu lehine anlamlı farklılık vardır.

\section{Yöntem}

\section{Araştıranın modeli}

İletişim becerileri geliştirme uygulamalarının okul yöneticilerinin iletişim becerilerine etkisinin araştırıldığı bu çalışmada deneme modellerinden öntest-sontest kontrol gruplu deneysel desen kullanılmıştır. Deneme modelleri, neden-sonuç ilişkilerini belirlemeye çalışmak amacı ile doğrudan araştırmacının kontrolü altında, gözlenmek istenen verilerin üretildiği araştırma modelidir (Karasar, 2014, s. 87; Büyüköztürk, 2001, s. 1-3; Fraenkel ve Wallen, 1996; Neuman, 2013). Öntest-sontest kontrol gruplu desenlerde, ilk olarak hazır bulunan iki gruptan hangisinin deney veya kontrol grubu olacağı yansız bir şekilde belirlenir. Ardından, her iki gruba da öntestler uygulanır. Uygulama sürecinde, deney grubunda belirlenen deneysel işlem uygulanırken kontrol grubunda herhangi bir işlem uygulanmaz. Son olarak, hem deney hem de kontrol grubuna sontestler uygulanarak araștırma sonlandırılır (Büyüköztürk ve diğerleri, 2009; Cohen ve diğerleri, 2007; Creswell, 2012). Araştırmanın deneysel modelinin simgesel görünümü aşağıdaki gibidir:

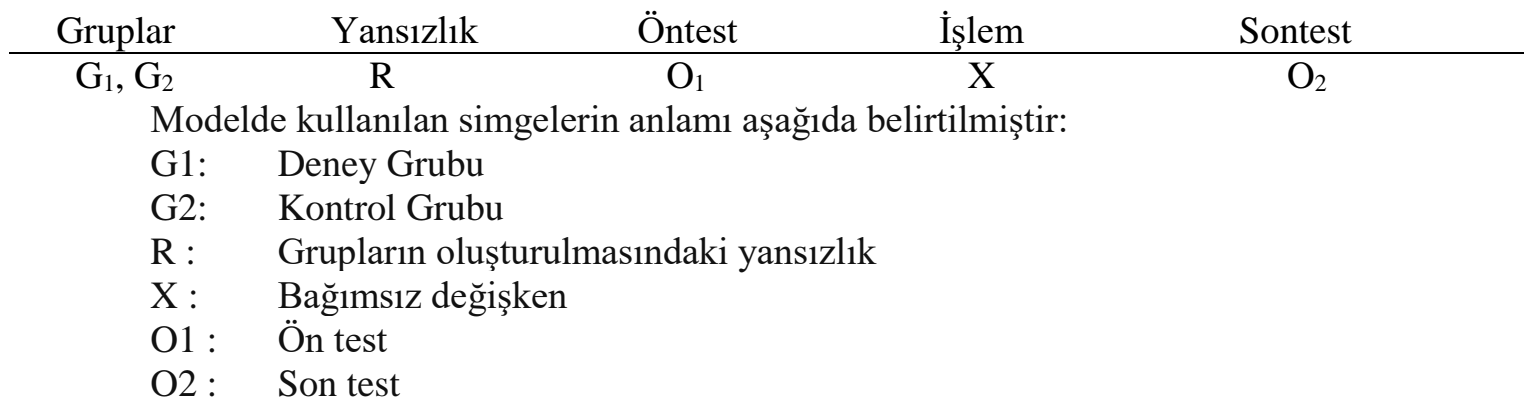

Deney ve kontrol grubunun yansız bir şekilde atandığı araştırmada, okul yöneticilerinin iletişim becerileri bağımlı değişken, iletişim becerileri geliştirme uygulamaları ise bağımsız değişken olarak belirlenmiştir. Burada bağımsız değişkenin, bağımlı değişken üzerinde etkili olup olmadığı sorusuna yanıt aranmıştır. 
Bu doğrultuda Elazığ il merkezinde yer alan okullarda 2014 yılındaki rotasyonuna tabi olmamış okul yöneticilerinden deney ve kontrol gruplarına deneysel işlemler uygulanmış ve uygulama sonucunda yönetici görüşlerine göre uygulamaların etkililiği değerlendirilmiştir.

\section{Evren ve örneklem}

Araştırmanın çalışma evrenini 2014-2015 eğitim-öğretim yılında Elazı̆̆ il merkezinde yer alan okullardaki (2014 yılındaki rotasyonuna tabi olmamış) okul yöneticileri oluşturmaktadır. Çalışma evreni ulaşılabilen evrendir. Çalışma evrenini belirlemenin en iyi yolu, amaca uygun ölçütler geliştirmek ve bu ölçütlere uyanları çalışma evrenine almaktır (Karasar, 2014, s. 110).

Çalışma grubunun oluşturulmasında amaçlı örnekleme tekniğine başvurulmuştur. Amaçlı örneklemede araştırmacı kimlerin seçileceği konusunda kendi yargısını kullanır ve araştırmanın amacına en uygun olanları örnekleme alır (Balc1, 2011,102). Araştırmada amaçlı örneklem kullanılmasının nedeni, 2014 yılında yönetici rotasyonunun yapılmasıdır. Okul yöneticisinin aynı okulda görev yapması çalışmanın amacına ulaşması için bir ön koşuldur. Bu kapsamda Elazı̆ il merkezinde yer alan ve 2014 yılındaki yönetici rotasyonuna tabi olmamış okul yöneticileri araştırmanın çalışma grubu olarak belirlenmiştir.

Araştırmalarda uygun örneklem büyüklüğünün ne olması gerektiğine ilişkin çeşitli kaynaklarda, evrenin büyüklügüne göre seçilebilecek örneklem büyüklükleri verilmektedir. $\mathrm{Bu}$ çalışmada Cochran (1962) tarafindan önerilen ve tabakalı örneklem büyüklüğünü saptamada yaygın olarak kullanılan örneklem belirleme formülü kullanılmıştır (Balcı, 2011, s. 106). Bu formüle göre;

$$
n=\frac{t^{2}(P Q) / d^{2}}{1+(1 / N) t^{2}(P Q) / d^{2}}
$$

$\mathrm{N}=$ Evren büyüklüğü

$\mathrm{n}=$ Örneklem büyüklüğü

$\mathrm{d}=$ Tolerans düzeyi $(.05)$

$\mathrm{t}=$ Güven düzeyinin tablo değeri (1.96)

$\mathrm{PQ}=(.50)(.50)=.25$ maksimum örneklem büyüklüğü için örneklem yüzdesi

Buna göre araştırma kapsamında belirlenen çalışma evreni 130, ulaşılmak istenen yönetici sayısı ise 40'tır. Çalışma evreni kapsamında yer alan deney ve kontrol grubunda toplam yönetici sayı1s1 130'dur. Genel olarak deneysel araştırmalarda her grupta en az 15 kişinin bulunması istenir (Balc1, 2011, s. 103). Bu doğrultuda deney ve kontrol grubunu oluşturan okul yöneticileri için her bir grupta 20 kişinin seçilmesine karar verilmiştir. Grupların oluşturulmasında, yöneticilerin görev türleri, görev yaptıkları okul türleri ve eğitim bölgeleri kriter olarak belirlenmiş ve bu kriterlere uygun olarak aradaki denkliğin sağlanmasına dikkat edilmiştir.

$\mathrm{Bu}$ doğrultuda çoğaltılan ölçme araçları gerekli yasal izinler alındıktan sonra örneklem dâhilindeki yöneticilere dağıtılmıştır. Ölçme aracının dağıtılması sürecinde, araştırmacı deney ve kontrol grubuna seçilen okullara giderek araştırmanın önemini vurgulayarak gerekli açıklamaları yapmış, yöneticilerin bu formları doldurması sağlanmıştır. Tüm formlar araştırmacının kendisi tarafından geri toplanmıştır. Araştırmanın deneysel işlemleri için deney ve kontrol grubundaki okul yöneticilerine öntest ve sontest olarak dağıtılan ölçme aracı sayısı 80'dir. Geri dönen bütün formlar geçerli kabul edilmiştir.

\section{Deney ve kontrol grubu için normallik testi}

Deney ve kontrol grubundaki okul yöneticilerinin başarı testi puanlarının karşılaştırılması için kullanılacak testin belirlenebilmesi amacıyla test puan dağılımlarının normal dağılım gösterip göstermediklerini tespit etmek için Shapiro-Wilks testi yapılmıştır. Kalaycı (2014, s. 6) normallik için yapılacak testlerde kurtosis ve skewness katsayıları kendi standart hatalarına bölünerek standartlaştırılmaktadır. Elde edilen standart değerler ( $\mathrm{z}$ değeri) kritik tablo 
değerleriyle karşılaştırılmaktadır. Skewness ve Kurtosis için bu değerler .05 anlamlılık düzeyinde +1.96 ve -1.96 aralığında yer almakta, anlamlılığın olması için bu değerlerin sıfır seviyesine yaklaşması gerekmektedir. Tablo 1, deney ve kontrol grubunda normal dağılımın olup olmadığına ilişkin değerleri göstermektedir.

Tablo 1

Deney ve Kontrol Grubuna İlişkin Normal Dağılım Değerleri

\begin{tabular}{lcc}
\hline & Deney Grubu & Kontrol Grubu \\
\hline$Z$ değeri (Skewness) & $-0,720$ & -0.220 \\
\hline$Z$ değeri (Kurtosis) & -1.095 & -0.001 \\
\hline Shapiro-Wilk (Sig.) & .163 & .155 \\
\hline
\end{tabular}

Tablo 1'e göre Skewness ve Kurtosis değerlerinin standartlaştırılmış değerleri (z değeri) ve Shapiro-Wilks test değerleri incelendiğinde deney ve kontrol grubunda yer alan okul yöneticilerinin başarı testi puanlarına ilişkin verilerin normal dağıldığı söylenebilir. Benzer sonuçlar normallik grafiğinde de gözlenmiştir. Veriler bir doğru üzerinde dağıldığı için grup için normalliğin varlığından söz edilebilir. Şekil 1 deney ve kontrol grubu için normal dağ 11 ım grafiğini göstermektedir.
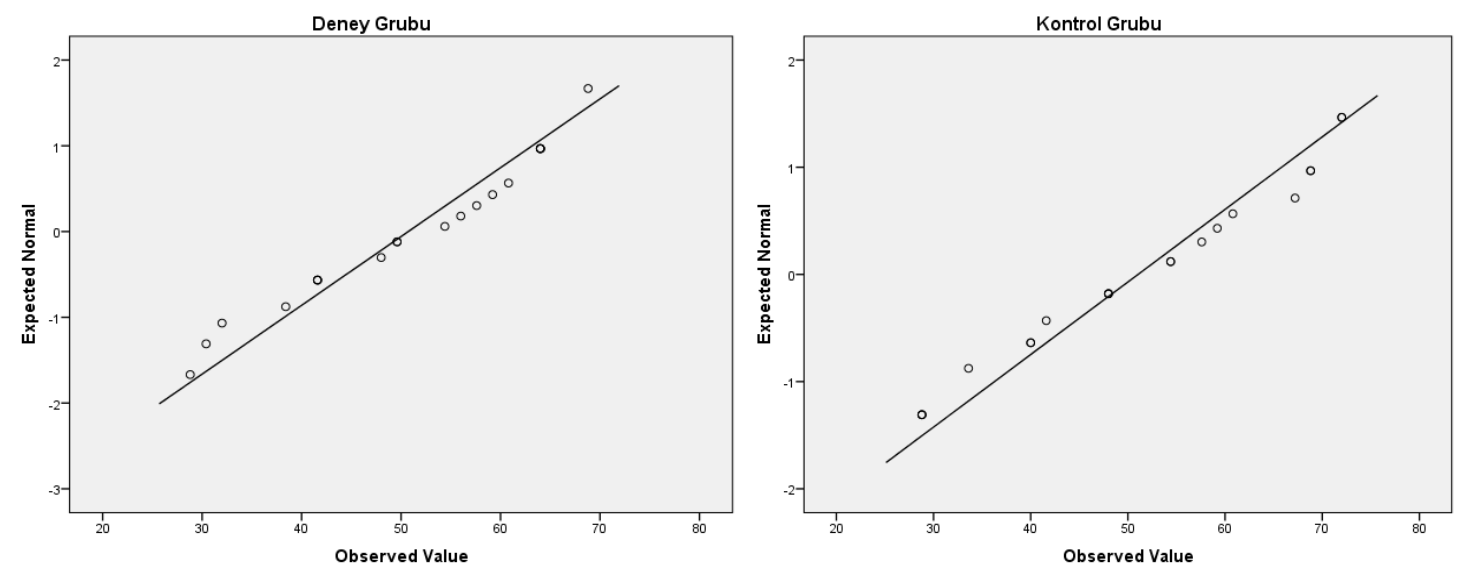

Şekil 1. Deney ve kontrol grubu için normal dağılım grafiği

\section{Başarı öntest puanlarına göre çalışma gruplarının sınanması}

Deney ve kontrol gruplarının başarı testinin öntest puanları arasındaki farkın anlamlılık düzeyini test etmek amacıyla bağımsız gruplar t-testi kullanılmıştır. Deney ve kontrol grubunu aynı analiz içinde değerlendirilmiştir. Sonuçlar Tablo 2'de sunulmuştur. Buna göre deney ve kontrol grubunda yer alan okul yöneticilerinin başarı testinden aldıkları öntest toplam puanları arasında anlamlı bir farklılığın olmadığı görülmüştür $(\mathrm{F}=.002 ; \mathrm{p}=.964)$. Diğer bir deyişle homojenlik varsayımının sağlandığı bulgusuna ulaşılmıştır.

Tablo 2

Deney ve Kontrol Grubunun Başarı Testi Öntest Puanlarına İlişkin Bağımsız Gruplar t-testi Sonuçları

\begin{tabular}{|c|c|c|c|c|c|c|c|c|}
\hline Gruplar & $\mathrm{N}$ & $\bar{X}$ & ss & $\mathrm{sd}$ & Levene & $\begin{array}{l}\text { An. } \\
\text { Düz. }\end{array}$ & $\mathrm{t}$ & $\begin{array}{l}\text { An. } \\
\text { Düz. }\end{array}$ \\
\hline Deney & 20 & 31.90 & 9.23 & \multirow{2}{*}{19} & \multirow{2}{*}{.002} & \multirow{2}{*}{.964} & \multirow{2}{*}{.594} & \multirow[b]{2}{*}{.560} \\
\hline Kontrol & 20 & 33.80 & 10.19 & & & & & \\
\hline
\end{tabular}


Ayrica deney ve kontrol grubunun ortalama puanlarının ( $\overline{\mathrm{X}}_{\text {deney }}=31.90$; $\left.\overline{\mathrm{X}}_{\text {kontrol }}=33.80\right)$ yakın değerde olduğu ve $[(\mathrm{t}=.594, \mathrm{p}<.05 \quad(\mathrm{p}=.560)]$ anlamlı farklılaşmanın olmadığ 1 tespit edilmiştir. Elde edilen bulgular grupların başarı öntestlerine göre yansız bir biçimde oluştuğunu göstermektedir.

\section{Uygulama hazırlık dönemi}

Okul yöneticilerinin belirlenmesi: Çalışmanın amacına uygun olarak 2014-2015 öğretim yılında yönetici rotasyonuna tabi olmayan okul yöneticilerinin seçimi için son atama dönemi (02.02.2015) beklenmiştir. Atamaların yapılmasının ardından Elazığ il merkezinde görev yapan anaokulu, ilkokul, ortaokul ve lisede görev yapan, yönetici rotasyonuna tabi olmamış okul yöneticilerinin isim listesinin alınması için İl Milli Eğitim Müdürlüğüne başvurulmuştur. Listede yer alan okul yöneticileri görev türü bakımından müdür ve müdür yardımcısı; okul türü bakımından anaokulu, ilkokul, ortaokul ve lise eşit bir şekilde seçilmeye çalışılmıştır. Eşitliğin mümkün olmadığı durumlarda dengeli bir seçim yoluna gidilmiştir. Buna göre ilk olarak listeden 10 müdür ve 10 müdür yardımcis1 deney grubu, 10 müdür ve 10 müdür yardımcıs1 kontrol grubu olarak seçilmiş, deney ve kontrol grupları kendi içlerinde tesadüfî olarak belirlenmiştir. Belirlenen okul yöneticileri bir bir ziyaret edilmiş, uygulamaların içeriği ayrıntılı olarak anlatılmış, uygulamalara katılmaları için ikna edilmiştir. Ancak ziyaret edilen 40 okul yöneticisinden iki tanesi yoğun iş yükü olduğu gerekçesi ile davetimizi geri çevirmiştir. Bu yöneticilerin yerine listeden denk olabilecek, benzer özelliklere sahip iki yönetici daha belirlenmiş, bu yöneticiler de ziyaret edilerek uygulamalara katılmaları için davet edilmiştir. İkinci seçimde yöneticilerin birçoğu rotasyona tabi olduğu için görevine devam eden yönetici sayısı kısıtlı olduğundan dolayı deney ve kontrol grubunda yer alan müdür ve müdür yardımcısı sayıları arasında yeniden bir denklik oluşturulmaya çalışılmıştır. Uygulamalara katılan okul yöneticilerinin görev türü ve okul türü değişkenlerine göre dağılımları Tablo 3'de sunulmuştur.

Tablo 3

Deney ve Kontrol Grubunda Yer Alan Yöneticilerin Okul Türü ve Görev Unvanlarına Göre Dağılımı

\begin{tabular}{llcc}
\hline Okul türü & Grup & Müdür & Müdür Yardımcis1 \\
\hline \multirow{2}{*}{ Anaokulu } & Deney & 1 & - \\
\cline { 2 - 4 } & Kontrol & - & - \\
\hline \multirow{2}{*}{ Ilkokul } & Deney & 4 & 2 \\
\cline { 2 - 4 } & Kontrol & 4 & 3 \\
\hline \multirow{2}{*}{ Ortaokul } & Deney & 3 & 3 \\
\cline { 2 - 4 } & Kontrol & 2 & 4 \\
\hline \multirow{2}{*}{ Lise } & Deney & 3 & 3 \\
\cline { 2 - 4 } & Kontrol & 4 & 19 \\
\hline Toplam & & 21 & \\
\hline
\end{tabular}

Sonraki adımda uygulamalara katılan deney ve kontrol grubundaki okullar tekrar ziyaret edilerek okul yöneticilerinin başarı testini (öntest); doldurmaları istenmiştir. Okul yöneticilerine gerekli açıklamalar yapılmış, bu yolla ölçeklerin daha doğru bir şekilde doldurulması sağlanmıştır. Ayrıca deney grubunda yer alan okul yöneticilerinin telefon numaraları ve e-mail adresleri alınmıştır. Uygulamaların yapılacağı uygun zamanın belirlenmesi için deney grubunda yer alan her bir okul yöneticisinin görüşüne başvurulmuştur. Yöneticilerin büyük çoğunluğu uygulamaların hafta içi herhangi bir gün, saat 3-5 arası yapılması yönünde ortak görüş bildirmişlerdir. Bu doğrultuda ilk iki hafta haftada bir gün ikişer saat, son iki hafta ise haftada bir gün dörder saat olmak üzere toplamda 12 saatlik yüz yüze uygulamaların yapılması planlanmıştır. 
Uygulamalarda görev alacak öğretim elemanının seçimi: Yüz yüze uygulamalarda hangi ögretim elemanının görev alacağının belirlenmesinde öncelikle Firat Üniversitesi personel web sitesi üzerinden özellikle iletişim, eğitim bilimleri, işletme ve teknoloji alanlarında görev yapan öğretim elemanlarının çalışma alanları taranmıştır. Araştırmanın birinci kısmında öngörülen regresyon modeli için belirlenen konularla ilgili çalışma alanları dikkate alınarak bu alanda çalışmaları olan öğretim elemanları tespit edilmiştir. Belirlenen öğretim elemanları ziyaret edilerek çalışmanın içeriği hakkında bilgi verilmiş, uygulamalarda görev alması ve uzmanlıklarını paylaşmaları konusunda ricada bulunulmuştur. Ancak görüşülen öğretim elemanlarından ikisi il dışına çıkacağı gerekçesiyle talebi geri çevirmiştir. Onların yerine çalışma alanları taranan diğer öğretim elemanlarından iki kişi ile görüşülmüş olumlu yanıt alınmıştır. Dolayısıyla ikisi iletişim, biri eğitim, ikisi işletme ve biri bilgisayar bölümünden olmak üzere toplam altı ögretim elemanı gönüllü olarak uygulamalarda görev almayı kabul etmişlerdir. Bu öğretim elemanları ile tekrar görüşülmüş araştırmanın içeriği hakkında detaylı bilgiler verilmiştir. Ayrıca uygulamalar için ortak zamanın belirlenmesi adına öğretim elemanlarından görüş alınmıştır.

Uygulamada Kullanılacak Öğretim Materyallerinin Hazırlanması: Araştırmada kullanılacak ögretim materyallerinden ilki bireylere mesleki yeterlik kazandırmak ve bireysel öğrenmeye rehberlik etmek amacıyla öğrenme materyali olarak tasarlanan modüllerdir. Araştırmada bireysel öğrenmeyi önceleyen modüllerin kullanılmasının nedeni; okul yöneticilerinin yoğun iş yüküne sahip olmasından dolayı, yüz yüze eğitimlere katılamadığı zamanlarda yaşanabilecek eksik öğrenmelerin önüne geçmektir. Modüller tasarlanırken öncelikle araştırmanın ilk kısımda önerilen modele ilişkin her bir değişkeni konu alan bir modül hazırlanması kararlaştırılmıştır. Dolayısıyla hazırlanan modüllerin konu başlıkları;

1. Etkili İletişim Süreci

2. Etkili İletişim Motivasyon ve İş Doyumu

3. Okul Kültürünün Oluşturulmasında İletişi̇imin Önemi

4. Stres Yönetimi ve İletişim

5. Çatışma Yönetimi ve İletişim

6. İletişim Teknolojileri olarak belirlenmiştir.

Sonraki aşamada her bir modülün konusu ile ilgili literatür taraması yapılmış ve Millî Eğitim Bakanlığı Mesleki ve Teknik Eğitim Genel Müdürlüğü Programlar ve Öğretim Materyalleri Dairesi Başkanlığının modül hazırlama kılavuzu dikkate alınarak modüller oluşturulmuştur. Bu kılavuza göre hazırlanan modüller açıklamalar, giriş, öğrenme faaliyeti, uygulama faaliyeti, ölçme ve değerlendirme, cevap anahtarı ve kaynakça kısımlarından oluşmaktadır. Bu kısımların her biri gerekli literatür taramasının ardından düzenlenmiştir. Daha sonra araştırmacı tarafindan modüllerin şekilsel düzenlemesi yapılarak son hali verilmiştir. Tamamlanan modüller üç alan uzmanı ve bir dil uzmanına sunulmuştur. Alınan dönütlerin ardından gerekli düzenlemeler yapılmış ve modüller baskıya hazır hale getirilmiştir. Bu işlemin ardından her bir modülün içeriğine uygun öğrenme sunuları hazırlanmıştır. Ayrıca öğrenmenin kalıcılığını arttırmak için bilgi kartları oluşturulmuş̧tur.

Hazırlanan modüller öğretim elemanlarının uzmanlık alanlarına göre dağıtılmış ve öğretim elemanlarından sunum günlerini belirlemeleri istenmiştir. Öğretim elemanlarının görüşleri doğrultusunda ve okul yöneticilerinin de görüşleri dikkate alınarak bir uygulama takvimi oluşturulmuştur. Oluşturulan takvim Tablo 4'te yer almaktadır. 
Tablo 4

Uygulama Takvimi

\begin{tabular}{llll}
\hline Ders & Tarih/Saat & Süre & Uygulama Adı \\
1. Ders & $\begin{array}{l}9 \text { Mart 2015 } \\
15: 30-17: 30\end{array}$ & 2 saat & Etkili İletişim Süreci \\
\hline 2.Ders & $\begin{array}{l}12 \text { Mart 2015 } \\
15: 30-17: 30\end{array}$ & 2 saat & $\begin{array}{l}\text { Etkili İletişim Motivasyon ve İş } \\
\text { Doyumu }\end{array}$ \\
\hline 3.Ders & $\begin{array}{l}19 \text { Mart 2015 } \\
15: 30-17: 30\end{array}$ & 2 saat & $\begin{array}{l}\text { Okul Kültürünün Oluşturulmasında } \\
\text { İletişimin Önemi }\end{array}$ \\
\hline 4.Ders & $\begin{array}{l}19 \text { Mart 2015 } \\
18: 00-20: 00\end{array}$ & 2 saat & Stres Yönetimi ve İletişim \\
\hline 5.Ders & $\begin{array}{l}26 \text { Mart 2015 } \\
15: 30-17: 30\end{array}$ & 2 saat & Çatışma Yönetimi ve İletişim \\
\hline 6.Ders & $\begin{array}{l}26 \text { Mart 2015 } \\
15: 30-17: 30\end{array}$ & 2 saat & İletişi̧m Teknolojileri \\
\hline
\end{tabular}

Öğretim yönetim sistemlerinin (ÖYS) oluşturulması: Araştırmanın uygulamalar kısmında yüz yüze eğitimlerin desteklenmesi, yoğun iş yüküne sahip okul yöneticilerinin gelemediği derslerde gözlenecek eksikliklerin giderilmesine dönük bireysel öğrenmenin gerçekleşmesi amacıyla açık kaynak kodlu öğretim yönetim sistemi olan moodle kullanılmıştır. Adından da anlaşılacağ üzere öğretim yönetim sistemi bir yönetim aracıdır ve eğitim içeriklerinin yönetimine, öğrenenler ve öğretenlerin izlenmesine, öğrenme öğretme süreçlerinin bireyselleştirilebilmesine olanak sağlayan bütünleşik bir sistemdir (Ozan, 2008, s. 61-62). Moodle ise güçlü, esnek, güvenilir ve hızla gelişim gösteren bir öğretim yönetim sistemi olması nedeniyle son zamanlarda çokça tercih edilmektedir. Bu kapsamda Fırat Üniversitesi Bilgi İşlem Daire Başkanlığı ile gerekli resmi yazışmalar yapılarak çalışma için gerekli olan web alanı alınmıştır. Alan adı "www.ibp.firat.edu.tr" olarak belirlenmiştir. Okul yöneticilerinin sisteme erişimlerini kolaylaştırmak için "www.gonulsener.com" isimli bir alan adı daha satın alınmıştır. Böylece yöneticilerin her iki adres üzerinden sisteme ulaşmaları sağlanmıştır. Hazırlanan ÖYS yukarıda belirtilen web adresleri üzerinden erişime açılmıştır (Şekil 2 ve 3).

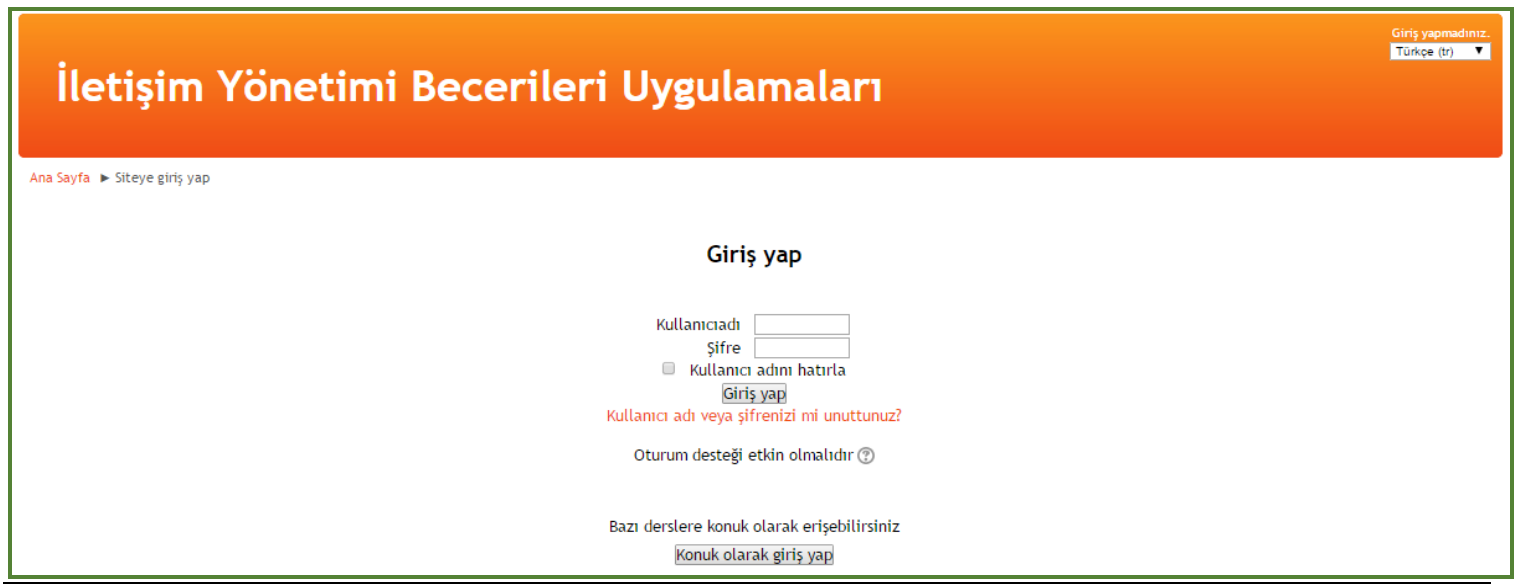

Şekil 2. Uygulama web sitesine giriş ekranı 


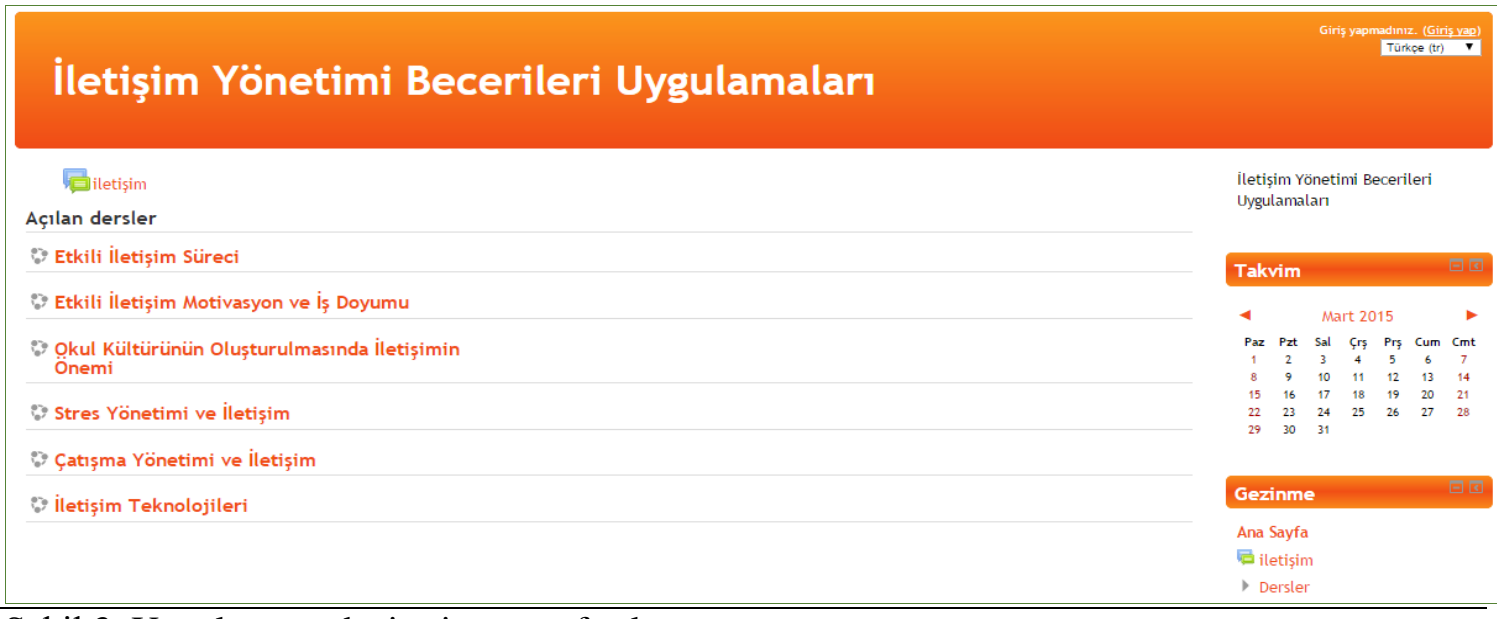

Şekil 3. Uygulama web sitesi ana sayfa ekranı

Okul yöneticilerinin kullanıcı adı ve şifreleri, uygulamalar başlamadan bir hafta önce sisteme giriş bilgilerinin yer aldığı resimli açıklamalar yöneticilerin e-mail adreslerine gönderilmiştir (Şekil 4).

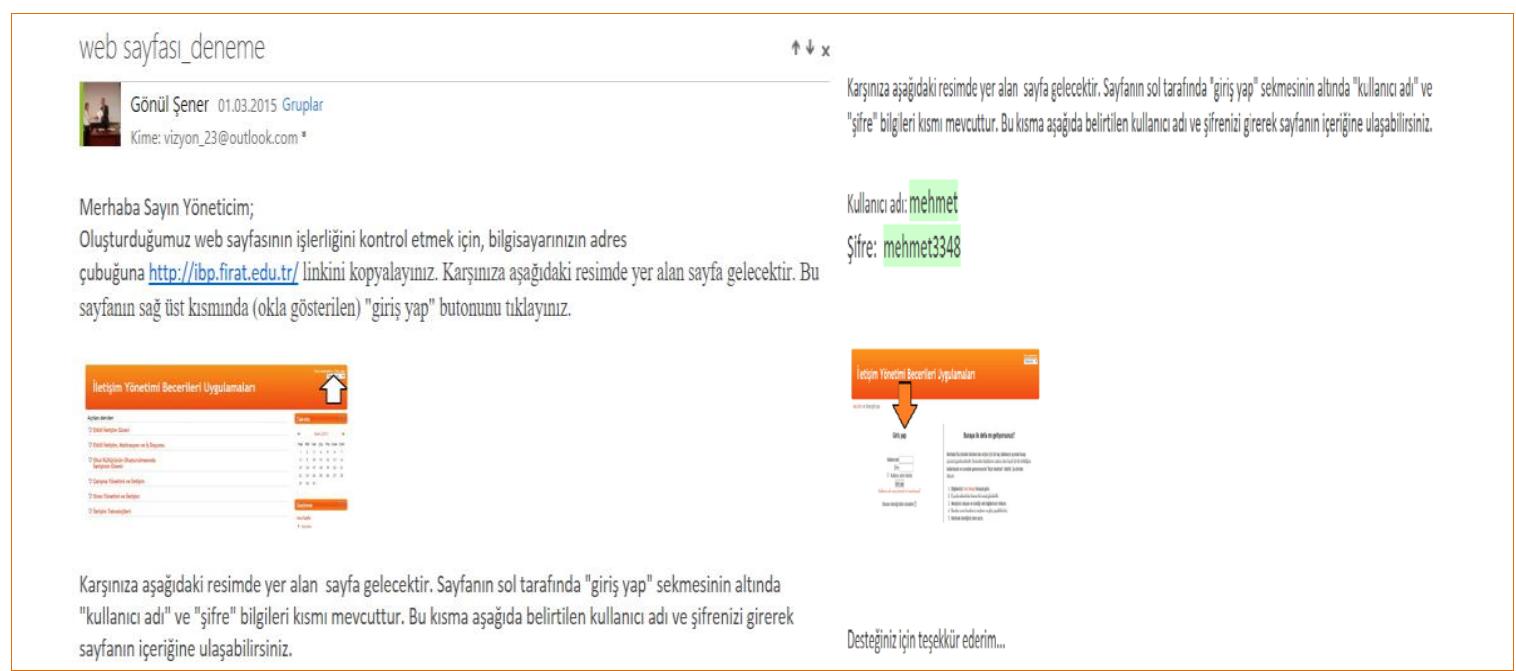

Şekil 4. Okul yöneticilerine gönderilen e-mail örneği

\begin{tabular}{|c|c|}
\hline \multicolumn{2}{|l|}{ Etkili İletişim Suireci } \\
\hline 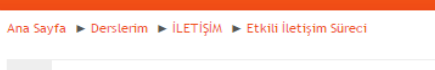 & Düzenlemeyiac \\
\hline 宜 Haber forumu & \multirow{2}{*}{ 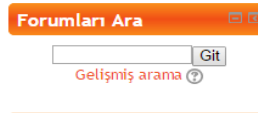 } \\
\hline 5 Mart - 11 Mart & \\
\hline 血Modü_1 & \multirow{6}{*}{ 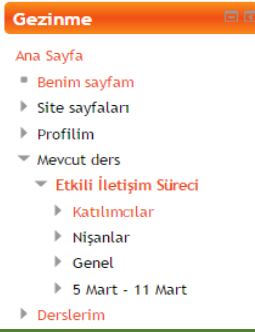 } \\
\hline 面 bilgi kart__1 & \\
\hline 首 bilgi kart__2 & \\
\hline (8) Ahmet șerif izgören & \\
\hline '终 etkili iletiş̣m & \\
\hline & \\
\hline
\end{tabular}

Şekil 5. Örnek ders ekranı 
Dersleri ekleme aşamasında ilk olarak sistem üzerinden iletişim kategorisi oluşturulmuştur. Bu kategori, her bir modül başlığı bir ders olacak şekilde düzenlenmiş, her bir ders için uygulama takvimine uygun olarak ders süreleri belirlenmiştir. Derslere ilişkin modüller, sunumlar, harici videolar, yüz yüze eğitimlerde kayıt altına alınan videolar ve bilgi kartları içeriğe eklenmiştir (Şekil 5).

Sonraki aşamada kullanıcıları sisteme eklemek için bir excel sayfasına okul yöneticilerinin ad, soyad, e- mail adresi ile araştırmacı tarafindan oluşturulan kullanıcı adı bilgileri eklenmiştir. Oluşturulan excel dosyası "CSV" uzantılı olarak kaydedilmiştir. Moodle sistem üzerinden kullanıcı yükle sekmesi kullanılarak katılımcıların kayıt işlemleri toplu olarak gerçekleştirilmiştir. Daha sonra dersler birer birer seçilerek her bir ders için katılımcıların rol tanımlamaları yapılmıştır. Katılımcıların sisteme girişleri kontrol edilmiştir.

Uygulamaların yapılacağı yerin hazırlanması: Uygulamaların yürütüleceği yüz yüze eğitimler için Fırat Üniversitesi Eğitim Fakültesi dekanlık toplantı salonunun kullanılmasına yönelik gerekli izinler alınmıştır. Derslerin öncesinde bilgisayar, projeksiyon, kamera gibi teknik araçların kurulumu yapılmıştır. Ayrıca basımı yapılan modüller her bir yönetici için masada hazır bekletilmiştir. Bunun yanında yöneticilere sunulmak üzere ikramlıklar hazırlanmıştır.

Uygulama öncesi iletişim: Uygulamaların başlama tarihinden yaklaşık bir hafta kadar önce hazırlanan etkinlik programı hem moodle sistem üzerinden paylaşılmış hem de yöneticilerin email adreslerine gönderilmiştir. Ayrıca her bir uygulama tarihi sms yoluyla bir gün öncesinden yöneticilere hatırlatılmıştır.

Öntestlerin uygulanması: Yukarıda sıralanan ve uzun bir çalışma zamanına yayılan faaliyetlerin tamamlanmasının ardından, araştırmanın deneysel deseni için öntestlerin uygulanmasına geçilmiştir. Uygulamaların yapılacağı tarihten yaklaşık bir ay kadar önce deney ve kontrol grubunda yer alan okullar ziyaret edilmiş, bu okullarda seçilen yöneticilere Başarı Testi öntest olarak uygulanmıştır.

\section{Uygulama dönemi}

Uygulamaların sorunsuz bir biçimde gerçekleştirilebilmesi için gerekli ön hazırlığın yapılmasının ardından, uygulamalara geçilmiştir. İlk uygulama günü gelen yöneticiler öncelikle dekanlık toplantı salonuna alınmıştır. Daha sonra araştırmacı tarafından araştırmanın amacı, içeriği ve yöneticilerden beklentilerin yer aldığı bir konuşma metni sunulmuştur. Her bir uygulama gününde uzmanlık alanlarına göre belirlenen öğretim elemanları sunumları için davet edilmiştir. Sunumlar rahat bir öğrenme ortamı içerisinde, karşılıklı fikir alışverişi şeklinde yürütülmüştür. Yapılan sunumlar kayıt altına alınmıştır. Sunum sonrası yöneticilere bir sonraki uygulama tarihi hatırlatılarak uygulamalar sonlandırılmıştır.

Uygulamaların son gününde ise deney grubundaki okul yöneticilerine Eğitim Bilimleri Enstitüsü ve Rektörlük makamından onaylı Eğitim Sertifikaları ile uygulamalara destek olan öğretim elemanları ve Milli Eğitim Müdürlüğü temsilcilerine Teşekkür Belgesi verilmiştir. Dört hafta süren uygulama sorunsuz bir şekilde tamamlanmıştır.

\section{Uygulama sonrası dönem}

Okul yöneticilerinin iletişim becerilerine katkı sağlamak için gerçekleştirilen uygulamaların ardından yaklaşı bir ay sonra deney ve kontrol grubundaki okullar tekrar ziyaret edilerek okul yöneticileri için başarı testi sontest olarak uygulaması yapılmıştır. Bu işlemler bir buçuk ay sürmüştür. Bunun ardından deney grubunda yer alan okul yöneticileri tekrar ziyaret edilerek yarı yapılandırılmış görüşme formunu doldurmaları istenmiştir. Nicel ve nitel verilerin toplanması ile uygulama sonrası işlemler sona ermiştir. 


\section{Veri toplama araçları}

Okul yöneticilerinin iletişim becerilerinin geliştirilmesi amacıyla tasarlanan uygulamaların etkiliğini belirlemek için araştırmacı tarafından başarı testi geliştirilmiştir. Başarı testi geliştirilirken önce literatür taraması yapılmış, konu ile ilgili farklı kaynaklardan yararlanılmıştır. Örgütsel iletişim ile ilişkili olan iletişim süreci, motivasyon/iş doyumu, okul kültürü, stres yönetimi, çatışma yönetimi ve iletişim teknolojileri konusunda çoktan seçmeli 70 sorudan oluşan soru havuzu oluşturulmuştur.

Hazırlanan sorular, uzman görüşüne sunulmuştur. Bu amaçla Fırat Üniversitesi Eğitim Fakültesi Eğitim Bilimleri Bölümünden iki öğretim üyesi, İletişim Fakültesinden iki öğretim görevlisi, BÖTE alanından bir okutman yine Fırat Üniversitesi Eğitim Bilimleri Bölümünden iki doktora öğrencisi ve bir Türkçe öğretmeni başarı testini, uygulama amacina uygunluk, dil, kapsam, içerik ve sayfa düzeni gibi farklı açılardan incelemişlerdir. Görüşlerine başvurulan uzmanlardan gelen öneri ve eleştiriler doğrultusunda sekiz soru çıkarılıp gerekli düzenlemeler yapıldıktan sonra beş şıktan oluşan 62 soruluk başarı testi hazırlanmıştır. Hazırlanan başarı testi Elazığ il merkezinde görev yapan 160 okul yöneticisine uygulanmıştır. Geri dönen testlerden iki tanesi geçersiz sayılmıştır. Böylece testin geçerlik ve güvenirlik işlemleri 158 kişi üzerinden hesaplanmıştır. Madde analizi işlemleri sonucunda her bir maddeye ait madde güçlük ve ayırıcılık indeksleri belirlenmiştir. Başarı testine dâhil edilen soruların çalışma grubu için zorluk derecesini belirlemek amaciyla her bir sorunun madde güçlük indeksi değerleri (pj) hesaplanmıştır. Madde güçlük indeksi, her bir maddenin doğru cevaplanma oranını göstermektedir. Madde güçlük indeksi, "0" ile "1" arasında değer almaktadır. Değerin sıfıra yaklaşması maddenin zor olduğu, bire yaklaşması ise maddenin kolay olduğu anlamına gelir. Genellikle madde güçlük indeksinin başarı testlerinde 0.50 civarında olması tercih edilir. $\mathrm{Bu}$ değer maddenin orta düzeyde zorluğa sahip olduğunu gösterir. Dolayısıyla orta zorluk düzeyindeki maddelerden oluşan testlerin güvenirlik düzeylerinin daha yüksek olduğu söylenebilir. Ayrıca testteki maddelerin her birinin güçlük düzeyi farklı olsa da bu maddelerin ortalamasına göre testin ortalama güçlülügünün 0.50 civarında olması istenilen bir durumdur (Çepni ve diğerleri, 2008; Tan ve diğerleri, 2002). Buna göre başarı testindeki maddelerin madde güçlük indeksleri değerleri .34 ile .84 arasında değişmektedir. Testin ortalama güçlüğü ise .56 olarak hesaplanmıştır. Dolayısıyla madde güçlük indeksi açısından testin güvenirlik düzeyinin yüksek olduğu söylenebilir.

Madde ayırıc1lık gücü indeksi (rjx) ise, bir maddenin yüksek ve düşük başarı düzeylerini ayırt etme derecesidir. Madde ayırıcılık gücü indeksi "-1" ile "+1" arasında değer almaktadır. Değerin sıfıra yaklaşması, maddenin üst ve alt grubu ayırıcılık gücünün düşük, +1 'e yaklaşması ise ayırıcılık gücünün yüksek olması anlamına gelir. Madde ayırıcılık gücü indeksinin negatif değerler alması, maddenin doğru cevaplanma oranının alt grupta daha yüksek olması anlamına gelir ve böyle bir madde testin amacina hizmet etmemekte ayrıca testin güvenirliğini de düşürmektedir (Baykul, 2000; Yıldırım, 1999; Tekin, 2009; Tan ve diğerleri, 2002). Madde Ayırıcılık Gücü İndeksi için kabul edilebilir değerler Tablo 5'de verilmiştir.

Tablo 5

Madde Ayırıcılık Gücü İndeksi

\begin{tabular}{ll}
\hline Maddenin Ayırt Etme İndeksi & Maddenin Değerlendirilmesi \\
\hline .40 ve üstü & $\begin{array}{l}\text { Çok iyi bir madde/olduğu gibi teste alınabilir/Ayırt edici bir } \\
\text { madde }\end{array}$ \\
\hline .30 ile .39 aras1 & Oldukça iyi bir madde/Düzeltme yapmadan da kullanılabilir \\
\hline .20 ile .29 arası & $\begin{array}{l}\text { Gözden geçirilmesi gereken madde/Düzeltildikten sonra } \\
\text { teste alınabilir }\end{array}$ \\
\hline .19 ve altı & Çok zayıf bir madde/Testten çıkarılmalı
\end{tabular}

Kaynak: Tekin, 2009, s. 249. 
Mevcut bilgiler dikkate alınarak, pilot uygulama yapılan testte yer alan maddeler gözden geçirilmiştir. Bu doğrultuda testte bulunan iki sorunun madde ayırıcılık gücü indeksinin .19'un altında olduğu için testten çıkarılmasına karar verilmiştir. Testte yer alan altı madde ise madde ayırıcılık gücü indeksi .20 ile .29 arasında değer aldığı için düzeltilerek teste dahil edilmiştir. Geriye kalan maddeler .30 ve üstünde değere sahip olduğu görülmüştür. Dolayısıyla testteki maddelerin madde ayırıcılık gücü indeksi değerlerinin .27 ile .66 arasında değiştiği görülmüştür.

Madde analizi işlemlerinin ardından 60 soruluk bir test elde edilmiştir. Elde edilen test puanları arasındaki iç tutarlı̆̆ incelemek amacıyla Kuder Richardson-20 (KR-20) kullanılmıştır. KR-20 güvenirlik katsayısı ölçme aracının iç turtarlılık ölçüsünü veren bir güvenirlik katsayısıdır ve testi oluşturan tüm maddelerin " $0-1$ " yöntemiyle puanlanması esastır (Tan ve diğerleri, 2002, s. 247). Kehoe (1995), 50'ye kadar maddeden oluşan çoktan seçmeli testler için KR-20 güvenirlik katsayısının .05; 50 maddenin üzerindeki testler için bu katsayının .80 olması gerektiğini belirtmiştir (Akt: Tan ve diğerleri, 2002, s. 247). Oluşturulan başarı testinin KR-20 değerinin .93 olduğu ve yüksek güvenirliğe sahip olduğu görülmüştür. Sonuç olarak test soruları yeterince ayırt edici, orta güçlükte ve çeşitli güçlük düzeylerinden sorular barındıran bir başarı testi olarak görülmektedir.

\section{Verilerin çözümlenmesi}

Deneysel model için verilerin çözümlenmesinde kişisel bilgilerin değerlendirilmesinde yüzde ve frekans değerlerine bakılmıştır. Hazırlık sürecinde araştırmacı tarafından hazırlanan başarı testinin pilot uygulaması sonrasında madde güçlük ve ayırıcılık indeksleri, standart sapma, varyans, ortalama, test güçlüğü ve KR-20 hesaplamaları yapılmıştır. Veriler SPSS 21 paket programında çözümlenmiştir.

Deney ve kontrol grubunun başarı testi öntest ve sontest puanları arasında anlamlı farklılığın olup olmadığını belirlemek için Bağımlı Gruplar t-testi uygulanmıştır. Bu test özellikle deneysel desene uygun olarak yürütülen araştırmalarda deney öncesi ve sonrası puanların karşılaştırmada anlamlı bir farklılığın olup olmadığını anlamak için kullanılır (Büyüköztürk, 2002; Larson-Hall, 2010; Pallant, 2011). Anlamlı farklılığın görüldüğü durumlarda ise Wilcoxon Sıralı Testler uygulanmıştır. Araştırmada deney ve kontrol grubunun görüşlerinin karşılaştırılmasında ise gruplar arasında anlamlı bir farklılığın olup olmadığını anlamak için Bağımsız Gruplar t-testi yapılmıştır. Anlamlı farklılığın görülmesi durumunda ise Mann Whitney U (MWU) testi kullanılmıştır.

$\mathrm{Bu}$ araştırmada istatistiksel anlamlılığın yanı sıra etki büyüklüğü de (Cohen d) hesaplanmıştır. Büyüköztürk'e göre Cohen standarize edilmiş etki büyüklügü indeksi olan d değeri, karşılaştırılan ortalamaların birbirinden kaç standart sapma uzaklaştı̆̆ını yorumlama imkânı vermektedir. Etki büyüklüğünün (Cohen d) hesaplanmasına ve yorumlanması sonuçların anlaşılabilirliğini arttırmaktadır (2011, s.44). Etki büyüklüklerini hesaplarken aşağıdaki formül kullanılmıştır:

$$
\mathrm{d}=\mathrm{t} \sqrt{\frac{\mathrm{N}_{1}+\mathrm{N}_{2}}{\mathrm{~N}_{1} \mathrm{~N}_{2}}}
$$

Hesaplamalar sonucunda elde edilen etki büyüklükleri bazı ölçüt değerler ile karşılaştırılarak yorumlanmıştır. Bu değerler aşağıda sıralanmıştır (Büyüköztürk, 2011, s. 44; Can, 2013, s. 121; Cohen, Manion ve Morrison, 2007, s.221).

$\checkmark 0.00 \leq$ etki büyüklüğü değeri $<0.10$ ise etki çok zayıf düzeyde

$\checkmark \quad 0.10 \leq$ etki büyüklüğü değeri $<0.30$ etki zayıf düzeyde

$\checkmark 0.30 \leq$ etki büyüklüğü değeri $<0.50$ etki orta düzeyde

$\checkmark \quad 0.50 \leq$ etki büyüklüğü değeri $<0.80$ etki güçlü düzeyde

$\checkmark$ Etki büyüklüğü değeri $\geq 0.80$ ise etki çok güçlü düzeyde 


\section{Bulgular}

Denence 1: İletişim yönetimi becerileri geliştirme uygulamalarına katılan deney grubundaki okul yöneticilerinin başarı testinin tümünden aldıkları öntest-sontest puanları arasında sontest puanları lehine anlamlı bir fark vardır.

Deney grubundaki okul yöneticilerinin başarı testinden aldıkları öntest-sontest toplam puanlarının karşılaştırılmasında normal dağılım gösterip göstermediğini belirlemek ve buna bağlı olarak kullanılacak teste karar vermek amacıyla öncelikle K-S normallik testi yapılmıştır. $\mathrm{Bu}$ teste göre deney grubu öntest $(\mathrm{K}=.192, \mathrm{p}=.052)$ ile sontest $(\mathrm{K}=.197, \mathrm{p}=.041)$ puanlarının normal dağılım göstermediği görülmüştür. Bu nedenle deney grubu öntest-sontest puanlarının karşılaştırılmasında nonparametrik bir test olan Wilcoxon işaretli sıralar testinin kullanılmasına karar verilmiştir. Sonuçlar Tablo 6' da gösterilmiştir.

Tablo 6

Deney Grubunun Başarı Testinden Aldığı Öntest-Sontest Puanlarına İlişkin Wilcoxon İşaretli Siralar Testi Sonuçları

\begin{tabular}{|c|c|c|c|c|c|}
\hline Öntest-Sontest & $\mathrm{N}$ & Sira Ort. & Siralar Topl. & $\mathrm{Z}$ & $\mathrm{p}$ \\
\hline Negatif Sira & 0 & .00 & .00 & \multirow{4}{*}{-3.922} & \multirow{4}{*}{$.000^{*}$} \\
\hline Pozitif Sira & 20 & 10.50 & 210.00 & & \\
\hline Eşit & 0 & & & & \\
\hline Toplam & 20 & & & & \\
\hline
\end{tabular}

Tablo 6'da iletişim yönetimi becerileri uygulamalarına katılan deney grubundaki okul yöneticilerinin, öntest ve sontest toplam puanlarının karşılaştırıldığı görülmektedir. Yapılan Wilcoxon işaretli sıralar testi sonucuna göre yöneticilerin öntest sontest puanları arasında anlamlı farklılığa rastlanmıştır $[Z=-3.922, \mathrm{p}=.000]$. Söz konusu bu farklılık, sontest puanları lehinedir. Buna bağlı olarak birinci denence doğrulanmıştır. Bu bulguya göre deney grubundaki okul yöneticilerinin iletişim yönetimi becerileri uygulamalarına katıldıktan sonra başarılarının $\operatorname{arttığı,~dolayısıyla~yapılan~uygulamaların~etkili~olduğu~söylenebilir.~}$

Denence 2: İletişim yönetimi becerileri geliştirme uygulamalarına katılmayan kontrol grubundaki okul yöneticilerinin başarı testinin tümünden aldıkları öntest-sontest puanları arasında sontest puanları lehine anlamlı bir fark vardır.

Kontrol grubundaki okul yöneticilerinin başarı testinden aldıkları öntest-sontest toplam puanlarının karşılaştırılmasında, yapılan K-S normallik testine göre, deney grubu öntest $(\mathrm{K}=.113, \mathrm{p}=.200)$ ile sontest $(\mathrm{K}=.118, \mathrm{p}=.200)$ puanlarının normal dağılım gösterdiği görülmüştür. $\mathrm{Bu}$ nedenle okul yöneticilerinin başarı testinden aldıkları öntest-sontest toplam puanlarının karşılaştırılmasında parametrik bir test olan bağımlı gruplar t-testi kullanılmıştır. Sonuçlar Tablo 7'de gösterilmiştir.

Tablo 7

Kontrol Grubunun Başarı Testinden Aldığı Öntest -Sontest Puanlarına İlişkin Bağımlı Gruplar t-testi Sonuçları

\begin{tabular}{|c|c|c|c|c|c|c|c|}
\hline Kontrol Grubu/Yönetici & $\mathrm{N}$ & $\bar{X}$ & sS & $\mathrm{r}$ & $\mathrm{t}$ & $\mathrm{p}$ & Cohen $\mathrm{d}$ \\
\hline Öntest & 20 & 31.90 & 9.23 & \multirow{2}{*}{.988} & \multirow{2}{*}{.456} & \multirow{2}{*}{.654} & \multirow{2}{*}{.14} \\
\hline Sontest & 20 & 31.70 & 7.78 & & & & \\
\hline
\end{tabular}

$* \mathrm{p}<.05$

İletişim yönetimi becerileri uygulamalarına katılmayan kontrol grubundaki okul yöneticilerinin, bağımlı gruplar t-testi sonucunda öntest $(\bar{X}=31.90)$ ve sontest $(\bar{X}=31.70)$ toplam puanlarında anlamlı farklılık görülmemiştir $[\mathrm{t}(19)=.456, \mathrm{p}=.654]$. Araştırmanın ikinci 
denencesi reddedilmiştir. Dolayısıyla kontrol grubundaki okul yöneticilerinin başarı puanlarında kayda değer bir değişim olmamıştır.

Denence 3: Deney ve kontrol grubundaki okul yöneticilerinin başarı testinden aldıkları sontest puanları arasında deney grubu lehine anlamlı farklılık vardır.

Deney ve kontrol grubunda yer alan okul yöneticilerinin başarı testinden aldıkları sontest toplam puanlarının karşılaştırılmasında bağımsız gruplar t-testi kullanılmıştır. Elde edilen sonuçlar Tablo 8'de gösterilmiştir.

Deney ( $\bar{X}=48.05$ ) grubundaki okul yöneticileri ile kontrol ( $\bar{X}=31.70)$ grubundaki okul yöneticilerinin sontest toplam puanlarının istatistiksel açıdan anlamlı biçimde farklılaştığ 1 görülmüştür [t(38)=6.69, p=.000]. Söz konusu fark, deney grubu lehine olduğu ortaya çıkmıştır. Buna bağlı olarak üçüncü denence doğrulanmıştır. Buna göre iletişim yönetimi becerileri uygulamalarına katılan deney grubundaki okul yöneticilerinin, uygulamalara katılmayan kontrol grubundaki okul yöneticilerinden daha başarılı olduğu söylenebilir.

Tablo 8

Deney ve Kontrol Grubunun Başarı Testinden Aldığı Sontest Puanlarına İlişkin Bağımsız Gruplar t-testi Sonuçları

\begin{tabular}{lccccccccc}
\hline Gruplar/Yönetici & $\mathrm{N}$ & $\overline{\mathrm{X}}$ & $\mathrm{ss}$ & $\mathrm{sd}$ & Levene & $\begin{array}{c}\text { An. } \\
\text { Düz. }\end{array}$ & $\mathrm{t}$ & $\begin{array}{c}\text { An. } \\
\text { Düz. }\end{array}$ & Cohen d \\
\hline Deney & 20 & 48.05 & 7.66 & 38 & .016 & .900 & $6.694 *$ & .000 & 2.11 \\
\hline Kontrol & 20 & 31.70 & 7.78 & & & & & \\
\hline *p $<.05$ & & & & & & & & &
\end{tabular}

Bağımsız gruplar t-testi, karşılaştırılan iki ortalama arasında anlamlı bir fark olup olmadığını ortaya koyar, ancak bu farkın büyüklüğü hakkında bilgi vermez. Büyüköztürk'e göre etki büyüklügünün (Cohen d) hesaplanması ve yorumlanması sonuçların anlaşılabilirliğini arttırmaktadır (2011, s.44). Bu nedenle araştırmada istatistiksel anlamlılı̆̆ın yanı sıra etki büyüklüğünün de (Cohen d) hesaplanmasına karar verilmiştir. Bu bağlamda hesaplanan etki büyüklüğü $(\mathrm{d}=2.11)$ farkın çok güçlü düzeyde olduğunu göstermektedir. Bu durum deney grubuna uygulanan iletişim yönetimi becerileri uygulamalarının anlamlı etkisinin olduğunu ortaya koymaktadir.

\section{Sonuç ve Öneriler}

İletişim yönetimi becerileri geliştirme uygulamalarına katılan deney grubundaki okul yöneticilerinin başarı testinin tümünden aldıkları öntest-sontest puanları arasında, sontest puanları lehine anlamlı bir fark olduğu bulunmuştur. Söz konusu bu farklılığın sontest puanları lehine olduğu görülmüştür. Dolayısıyla deney grubundaki okul yöneticilerinin iletişim yönetimi becerileri uygulamalarına katıldıktan sonra başarılarının arttığı ve yapılan uygulamaların etkili olduğu söylenebilir.

İletişim yönetimi becerileri geliştirme uygulamalarına katılmayan kontrol grubundaki okul yöneticilerinin başarı testinin tümünden aldıkları öntest-sontest puanları arasında, sontest puanları lehine anlamlı bir fark olmadığı bulunmuştur. Kontrol grubunda yer alan okul yöneticilerinin başarı testinden aldıkları öntest-sontest toplam puanlarında anlamlı farklılık görülmemiştir. Dolayısıyla kontrol grubundaki okul yöneticilerinin başarı puanlarında kayda değer bir değişim olmadığı sonucuna ulaşılmıştır. Yapılan çalışmalar okul yöneticilerinin iletişim becerilerinin yetersiz olduğunu ortaya koymaktadır (Arslantaş, 2002; Celep, 1992; Çelik, 2007; Çetinkaya, 2011; Dağl1, 2000; Demircan, 2001; Ersoy, 2006; Güneş, 2007; Gürses, 2006; Özbek, 1998). Okulda yöneticileri; öğretmenler, öğrenciler ve veliler arasında karşılıklı saygı ve güvene dayalı devam eden bir iletişim süreci sağlamalıdır. Bu süreç öğrencilerin gelişimini ve akademik başarısını olumsuz etkileyebilmektedir. Birçok öğrenci, okuldaki iletişim ile ilgili sorunlardan dolayı okuldan ayrılmakta veya başarısız olmaktadır. Okullardaki 
iletişim sürecinin bütün boyutlarıyla sağlıklı bir şekilde devam ettirilmesinde yöneticilere önemli görevler düşmektedir.

Deney ve kontrol grubundaki okul yöneticilerinin başarı testinden aldıkları sontest puanları arasında, deney grubu lehine anlamlı bir fark olduğu bulunmuştur. Deney grubundaki okul yöneticileri ile kotrol grubundaki okul yöneticilerinin sontest toplam puanlarının, istatistiksel açıdan anlamlı biçimde farklılaştığı görülmüş̧ür. Söz konusu farkın, deney grubu lehine olduğu ortaya çıkmıştır. Buna göre iletişim yönetimi becerileri uygulamalarına katılan deney grubundaki okul yöneticilerinin uygulamalara katılmayan kontrol grubundaki okul yöneticilerine göre daha başarılı olduğu sonucuna ulaşılmıştır.

\section{Öneriler}

- Araştırma sonuçları iletişim yönetimi becerileri uygulamalarının okul yöneticilerinin başarılarına ve iletişim becerilerine katkı sağladığını göstermiştir. Bu bağlamda Milli Eğitim Bakanlığı bu tür kişisel ve mesleki gelişim uygulamalarına sıklıkla yer vermelidir.

- Okul yöneticileri, iletişimin amacını iyi belirlemeli, iletişim, iletişime engel olan faktörler, sağliklı ve etkili iletişim için gereken koşullar, iletişim becerilerinin geliştirilmesi, insan ilişkileri gibi konularında bilgi sahibi olmalıdırlar. $\mathrm{Bu}$ amaçla, üniversitelerle işbirliği yapılarak alan uzmanlarından yararlanılmalı ve daha kapsamlı seminerler, hizmet içi etkinlikler düzenlenmelidir.

- Eğitim fakültelerinde iletişim becerileri ile ilgili programlar veya dersler konulmalı, yöneticiliğe başlayacakların iletişim becerileri ile ilgili eğitime alındıktan sonra göreve başlatılmaları, görevde olanların hizmet içi eğitimlerle iletişim becerilerinin geliştirilmesi için kurs-seminer ve eğitimler verilmelidir.

- Okul yöneticileri kurumlarında örgütsel iletişim kanallarını devamlı açık tutarak, iletişimi engelleyen etkenleri tanımalı ve bunları en aza indirecek önlemler almalıdırlar.

- Milli Eğitim Bakanlığı tarafından hazırlanan hizmet içi eğitim faaliyetleri zengin içerikli hazırlanıp, bu doğrultuda yürütülmelidir.

- $\mathrm{Bu}$ çalışma sadece resmi okullarda gerçekleştirilmiştir. Okul yöneticilerinin iletişim becerilerinin özel okullarla karşılaştırılmalı olarak incelendiği araştırmalar yapılabilir.

- Benzer çalışmalar eğitim kurumlarında çalışan diğer personeller için de gerçekleştirilebilir ve sonuçlar karşılaştırılabilir.

\section{Kaynaklar}

Arslantaş, İ. (2002). Ortaögrretim okullarında iletişim (Yayımlanmamış yüksek lisans tezi). Dicle Üniversitesi Sosyal Bilimler Enstitüsü, Diyarbakır.

Aydoğan, İ. ve Kaşkaya, A. (2010). İlköğretim okulu yöneticilerinin iletişim becerilerinin yönetici ve öğretmen görüşlerine göre değerlendirilmesi. Gazi Üniversitesi Eğitim Fakültesi Dergisi, 30(1), 1-16.

Balc1, A. (2011). Sosyal bilimlerde araştırma: yöntem, teknik ve ilkeler (9. baskı). Ankara: Pegema Yayincilik.

Baykul, Y. (2000). Ě̆itimde ve psikolojide ölçme. Ankara, ÖSYM.

Bursalığlu, Z. (2011). Okul yönetiminde yeni yapı ve davranış (16. baskı). Ankara: Pegem A Yayıncilik.

Büyüköztürk, Ş. (2001). Deneysel desenler, öntest-sontest, kontrol grubu desen ve veri analiz kitabı (1. baskı). Ankara: Pegema Yayıncılık.

Büyüköztürk, Ş. (2002). Faktör analizi: temel kavramlar ve ölçek geliştirmede kullanımı. Kuram ve Uygulamada Ĕ̈itim Yönetimi, 32, 470-483.

Büyüköztürk, Ş. (2011). Sosyal bilimler için veri analizi el kitabı. Ankara: Pegem Akademi Yayıncilik.

Büyüköztürk, Ş., Kılıç Çakmak, E., Akgün, Ö. E., Karadeniz, Ş. ve Demirel, F. (2009). Bilimsel araştırma yöntemleri (4. bask1). Ankara: PegemA Akademi. 
Callan, V. (1993). Subordinate-manager communication in different sex dyads: consequences for job satisfaction. Journal of Occupational \& Organizational Psychology, 66(1), 1328.

Can, A. (2013). SPSS ile bilimsel araştırma sürecinde nicel veri analizi. Ankara: Pegem Akademi Yayıncilik.

Celep, C. (1992). İlkokullarda yönetici öğretmen iletişimi, Hacettepe Üniversitesi Eğitim Fakültesi Dergisi, 8, 301-316.

Cohen, L., Manion, L. ve Morrison, K. (2007). Research methods in education (6th edition). London, Routledge Cottrell.

Creswell, J. W. (2012). Educational research: planning, conducting, and evaluating quantitative and qualitative research (4th edition). New Jersey, Pearson Education, Inc.

Çelik, Ç. (2007). İlköğretim okulu müdürlerinin iletişim becerileri ile tükenmişlik düzeyleri arasındaki ilişki (Gaziantep ili merkez ilçeleri örneği) (Yayımlanmamış yüksek lisans tezi). Gaziantep Üniversitesi Sosyal Bilimler Enstitüsü, Gaziantep.

Çelikkaya, H. (1998). Fonksiyonel eğitim sosyolojisi. (2. baskı). İstanbul, Alfa Yayın Dağıtım.

Çepni, S., Bayrakçeken, S., Yılmaz, A., Yücel, C., Semerci, Ç., Köse, E., Sezgin, F., Demircioğlu, G. ve Gündoğdu, K. (2008). Ölçme ve değerlendirme. Ankara: Pagem Akademi.

Çetinkaya, İ. (2011). Ortaöğretim okul müdürlerinin liderlik stilleri ve iletişim becerileri arasındaki ilişki (Yayımlanmamış yüksek lisans tezi). Gazi Üniversitesi Eğitim Bilimleri Enstitüsü, Ankara.

Dağl1, A. (2000). İlköğretim okullarında iletişim. Çağdaş Eğitim Dergisi, (265), 37-42.

Demir, K. (2000). Örgütlerde iletişim yönetimi yönetimde çağdaş yaklaşımlar. Ankara: Anı Yayıncilik.

Demircan, A. (2001). İlköğretim okulu müdürleri yöneticilik becerilerine ne derece sahiptir? (Yayımlanmamış yüksek lisans tezi). Yıldız Teknik Üniversitesi Sosyal Bilimler Enstitüsü, İstanbul.

Eroğlu, E. (2011). Illetişimci liderlik. Konya: Nüve Kültür Merkezi.

Ersoy, S. (2006). İlköğretim Okullarında yönetici ve ögretmenler arasındaki iletissim sorunları (Van ili örneği) (Yayımlanmamış yüksek lisans tezi). Yüzüncü Yıl Üniversitesi Sosyal Bilimler Enstitüsü, Van.

Fraenkel, J. R. ve Wallen, N. E. (1996). How to design and evaluate research in education (3rd. edition ). New York: Mc Graw Hill Higher Education.

Geçikli, F. (2004). Örgütsel iletişimin yöneticiler açısından değerlendirilmesi ve örgütsel iletişim yönetimi. İstanbul Üniversitesi İletişim Fakültesi Dergisi, 20(1), 107-116.

Güneş, K. (2007). İlköğretim okulu öğretmenlerinin okul müdürlerinin iletişim ve motivasyon becerileri ile ilgili algı ve beklentileri (İstanbul ili Avrupa Yakası örneği) (Yayımlanmamış yüksek lisans tezi). Yeditepe Üniversitesi, Sosyal Bilimler Enstitüsü, İstanbul.

Güngör, N. (2011). Iletişsim kuramlar, yaklaşımlar. Ankara: Siyasal Kitabevi.

Gürses, T. (2006). Eğitim Örgütlerinde yöneticilerin etkili iletişim kurma becerilerinin belirlenmesine yönelik bir araştırma (Kütahya merkez ilçe örneği) (Yayımlanmamış yüksek lisans tezi). Dumlupınar Üniversitesi, Sosyal Bilimler Enstitüsü, Kütahya.

Karasar, N. (2014). Bilimsel araştırma yöntemi. Ankara: Nobel Yayın Dağıtım.

Larson-Hall, J. (2010). A guide to doing statistics in second language research using SPSS. New York: NY, Routledge.

Neuman, W. L. (2013). Toplumsal araştırma yöntemleri (6. baskı). S. Özge (Çev.). İstanbul: Yayınodas1 Yayınc1lik.

Orhon, N. ve Eriş, U. (2012). Iletişsim bilgisi. N. Orhon ve U. Eriş (Yay. haz.). Eskişehir: Anadolu Üniversitesi Yayınları, Önsözden. 
Özbek, S. (1998). İlköğretim öğretmenlerinin okul müdürlerinin iletişim ve motivasyon becerilerine ilişkin algı ve beklentileri-İzmir ili örneği (Yayımlanmamış yüksek lisans tezi). Dokuz Eylül Üniversitesi Sosyal Bilimler Enstitüsü, İzmir.

Özdemirci, F. (2006, Mayıs). Kurumsal iletişim ve belge yönetimi. I. Uluslararası Bilgi Hizmetleri Sempozyumu: Illetişim, İstanbul, içinde (ss. 315-324). Türk Kütüphaneciler Derneği İstanbul Şubesi, İstanbul.

Pallant, J. (2011). SPSS: Survival manual (4th edition). Crowsnest: NSW, Allen \& Unwin.

Roebuck, C. (2000). Etkili iletişim. A. C. Akkayunlu (Çev.). İstanbul: Doğan Kitap.

Saran, U. (2001). Küresel değişim dinamiklerinin kamu yönetimi alanındaki etkileri. Türk İdare Dergisi, 73(433), 41-49.

Tan, K. C. D., Goh, K. N., Chia, S. L. ve Treagust, D. F. (2002). Development and application of a two-tier multiple choice diagnostic instrument to assess high school students' understanding of inorganic chemistry qualitative analysis. Journal of Research in Science Teaching, 39(4), 283-301.

Taymaz, H. (2000). Okul yönetimi. (5. baskı). Ankara: PegemA Yayıncılık.

Tekin, Ö. B. (2009). Örgütlerde elektronik posta kullanımının örgütsel iletişime etkileri ve Paristanbul Dizayn Ajansı'nda bir uygulama örneği (Yayımlanmamıs yüksek lisans tezi). Anadolu Üniversitesi Sosyal Bilimler Enstitüsü, Eskişehir.

Tengilimoğlu, D. (2005). Hizmet işletmelerinde liderlik davranışları ile iş doyumu arasındaki ilişskinin belirlenmesine yönelik bir araştırma. Ticaret ve Turizm Eğitim Fakültesi Dergisi, 1, 23-45.

Uzun, T. ve Ay1k, A. (2016). Okul müdürlerinin iletişim becerileri ile öğretmenlerin genel ve örgütsel sinizm tutumları arasındaki ilişkilerin incelenmesi. Mersin Üniversitesi Eğitim Fakültesi Dergisi, 12(2), 672-688.

Yıldırım, C. (1999). Ĕgitimde ölçme ve değerlendirme. Ankara: ÖSYM Yayınları.

\section{Extended Abstract}

\section{Introduction}

Communication between administrators and employees is an important factor for the effectiveness of the performance in the organization. It is the duty of the manager to ensure unity and solidarity among the employees. School administrators should be able to express their thoughts, ideas and feelings freely and effectively and should be a good listener with convincing, leadership qualities to be able to accomplish all of them. In educational administration, the transmission of orders, information, ideas, thoughts and problems between employees and within the school in a healthy way depends on the accurate and effective functioning of communication. The rapid changes and developments we have experienced today have increased the need for administrators with communication competence (Demir, 2000). The disorders in the functioning of the communication process are included among the reasons for the failure of many organizations. Failure to maintain this process as required may lead to high cost losses such as time, money and qualified work force (Geçikli, 2004, p.106-107). For this reason, school administrators are expected to be experts in communication skills in ensuring organizational effectiveness. The provision of this expertise is possible with the trainings received.

In the literature reviewed in detail, although it is seen that theoretical information and descriptive studies regarding the administrative dimension of communication are largely included, applied studies aimed at providing administrators with communication management skills have not been found. Furthermore, the studies carried out show that school administrators' communication skills are inadequate (Arslantaş, 2002; Celep, 1992; Çelik, 2007; Çetinkaya, 2011; Dağl1, 2000; Demircan, 2001; Ersoy, 2006; Güneş, 2007; Gürses, 2006; Özbek, 1998). In the school administrators should provide an ongoing communication process based on mutual respect and trust among teachers, students and parents. This process may negatively affect the development and academic success of students. Many students leave the school or fail due to the 
problems related to communication in the school. Administrators have important duties in maintaining the communication process in the school in a healthy way with all dimensions.

With this study, it is aimed that administrators are aware of communication with respect to ensuring effectiveness in their schools and exhibit effective communication skills in their communication with teachers and students and parents, these skills contribute to their personal and professional development and also fill the gap in the field. The main aim of the study is to ensure the development of school administrators' communication skills with module-based applications. The following hypotheses were tested for the realization of this aim.

Hypothesis 1: There is a significant difference between the pretest-posttest scores received by school administrators in the experimental group who participated in communication management skills development applications from the entire achievement test, in favor of posttest scores.

Hypothesis 2: There is a significant difference between the pretest-posttest scores received by school administrators in the control group who did not participate in communication management skills development applications from the entire achievement test, in favor of posttest scores.

Hypothesis 3: There is a significant difference between the post-test scores received by school administrators in the experimental and control groups from the achievement test, in favor of the experimental group.

\section{Method}

In this section of the study in which the effect of communication skills development applications on school administrators' communication skills was investigated, the experimental design with pretest-posttest control group was used.

The population of the study consisted of school administrators in the schools located in the city center of Elazı ğ province (have not been subject to 2014 rotation) in the 2014-2015 academic year. The purposeful sampling method was used in the formation of the study group. It was decided that 20 people would be selected in each group for school administrators constituting the experimental and control groups. Administrators' task types, types of the schools where they worked, and education zones were determined as criteria in the formation of groups, and attention was paid to ensure equivalence between them in accordance with these criteria.

A 60-question achievement test was developed by the researcher to determine the effectiveness of the applications designed to improve the communication skills of school administrators. It was determined that the achievement test developed had a KR-20 value of .93 and high reliability. This indicates that the test questions are sufficiently distinctive and moderately difficult, and that it is an achievement test containing questions at various difficulty levels.

In the analysis of the data for the experimental model, the percentage and frequency values were analyzed in the evaluation of personal information. Item difficulty and discrimination indices, standard deviation, variance, mean, test difficulty and KR-20 calculations were performed after the pilot application of the achievement test prepared by the researcher during the preparation period. Data were analyzed in the SPSS 21 package program.

The dependent groups' t-test was applied to determine whether there was a significant difference between the pretest and post-test scores of the achievement test of the experimental and control groups. Wilcoxon signed rank test was applied when a significant difference was observed. In the comparison of the views of the experimental and control groups in the study, the Independent Groups t-test was performed to see if there was a significant difference between the groups. Mann Whitney U (MWU) test was used when a significant difference was observed. Furthermore, the statistical significance and the effect size (Cohen d) were calculated in the study. 


\section{Result and Discussion}

A significant difference was determined between the pretest-posttest scores received by school administrators in the experimental group who participated in communication management skills development applications from the entire achievement test, in favor of posttest scores. Within the scope of the study, a significant difference was found between the pretest-posttest total scores of school administrators in the experimental group who participated in communication management skills applications. It was seen that this difference was in favor of posttest scores. Therefore, it can be said that the success of school administrators in experiment group increased after they participated in communication management skills applications and that the applications made are effective.

It was determined that there was not a significant difference between the pretest-posttest scores received by school administrators in the control group who did not participate in communication management skills development applications from the entire achievement test, in favor of posttest scores. No significant difference was found between the pretest-posttest total scores received by the school administrators in the control group from the achievement test. Therefore, it was concluded that there was no significant change in the achievement scores of school administrators in the control group.

It was determined that there was a significant difference between the post-test scores received by school administrators in the experimental and control groups from the achievement test, in favor of the experimental group. It was observed that the total posttest scores of the school administrators in the experimental group and the school administrators in the control group were statistically significantly different. It was determined that this difference was in favor of the experimental group. Accordingly, it was concluded that school administrators in the experimental group who participated in communication management skills applications were more successful compared to school administrators in the control group who did not participated in the applications.

\section{Suggestions}

- The research results have shown that communication management skills applications have contributed to the success and communication skills of school administrators. In this context, the Ministry of National Education should frequently include such personal and professional development applications.

- Programs or courses on communication skills should be included in faculties of education, individuals who will start to work as administrators should be started after receiving training on communication skills, and courses, seminars and trainings should be given for the development of the communication skills of those who are on duty with in-service trainings.

- School administrators should know the factors that prevent communication by keeping the organizational communication channels open and should take precautions to minimize them.

- This study was conducted on internal and external stakeholders only in public schools. It is possible to conduct studies in which school administrators' communication skills are investigated in comparison with private schools.

- Similar studies can also be conducted for other employees working in educational institutions, and the results can be compared. 